\title{
OIL SHALE RESOURCES FOR OIL PRODUCTION
}

\author{
E. REINSALU*, I. VALGMA \\ Department of Mining \\ Tallinn University of Technology \\ 5 Ehitajate Rd., 19086 Tallinn, Estonia
}

\begin{abstract}
Estonian oil shale reserves have been estimated proceeding from the requirements of power plants. Today, when the possibility of selling shale oil in larger amounts is becoming a reality, the oil shale reserve has to be evaluated according to the criteria of oil production. The solid-energycarrier method of processing as a relatively new way of oil generation has economical advantages and has therefore to be considered at calculating cutoff grade for mining. The basis for using this approach has been worked out by GIS modelling. Preliminary calculations showed that the cut-off grade of oil shale could be lower than today's $35 \mathrm{GJ} / \mathrm{m}^{2}$. This could increase the mineable resource of Estonian oil shale.
\end{abstract}

Estonian oil shale mineable (active) reserves are estimated according to the energy rating of the bed $>35 \mathrm{GJ} / \mathrm{m}^{2}$ (cut-off-grade). An auxiliary criterion for marginally economic (passive) reserves is energy rating that should be at least $25 \mathrm{GJ} / \mathrm{m}^{2}$. These cut-off-grades have been calculated by Department of Mining of Tallinn University of Technology proceeding from the requirements of existing power plants ten years ago when marketing of shale oil was problematic and oil processing conditions were not taken into consideration $[1,2]$.

Below we shall analyse what will happen when the situation will change. Two shale oil processing technologies are in use in Estonia today. The old way - processing of lump oil shale (LOS-process) - needs separated high calorific $(12 \mathrm{MJ} / \mathrm{kg}$ ) oil shale of the class $25-125 \mathrm{~mm}$. The relatively new process with solid heat carrier (SHC-process) can produce oil from nonenriched material (run-of-mine oil shale, ROM).

Separation plants at mines were built for the LOS-process [3]. In accordance with the needs of consumers ROM was separated into two classes: small-grain (from 0 to $25-50 \mathrm{~mm}$ ) and coarse-grain (from 25 to $50-125 \mathrm{~mm}$ ) material. Small-grain oil shale is sold to power plants as fuel (fuel oil shale, FOS). Coarse material goes to separation plant as feed. A beneficial product of separating is raw material for oil processing (process oil shale, POS), and

\footnotetext{
*Corresponding author: e-mail ere@cc.ttu.ee
} 
limestone containing organics remains a waste. The losses of organic material (kerogen) with waste are $2-7 \%$. Both waste mass and losses increase proportionally with enhancing calorific value of the enriched product (POS). Accordingly the yield of POS is smaller and its cost price higher:

$$
C_{\mathrm{POS}}=C_{\text {feed }} / s_{\mathrm{POS}},
$$

where (see Table 1):

$C_{\mathrm{POS}}-$ cost prise of oil shale for the LOS-process,

$C_{\text {feed }}$ - cost price of separation feed; equal to cost price of ROM $\left(C_{\mathrm{ROM}}\right)$,

$S_{\mathrm{POS}}-$ yield of oil shale for processing.

Likewise,

$$
C_{\mathrm{TOS}}=C_{\mathrm{ROM}} / s_{\mathrm{TOS}}=C_{\mathrm{ROM}} /\left(1-s_{\mathrm{FOS}}-s_{\mathrm{POS}}\right)=C_{\mathrm{ROM}} /\left(1-s_{\mathrm{WASTE}}\right),
$$

where $C_{\mathrm{TOS}}-$ cost price of production at mine, trade oil shale, TOS is the sum of fuel oil shale and process oil shale in the following order:

$$
\mathrm{TOS}=\mathrm{FOS}+\mathrm{POS},
$$

and $s_{\mathrm{TOS}}, s_{\mathrm{FOS}}, s_{\mathrm{POS}}$ and $s_{\mathrm{WASTE}}$ are the yields of trade oil shale, fuel oil shale,

\begin{tabular}{|c|c|c|c|c|}
\hline \multirow{2}{*}{ Parameters } & \multirow{2}{*}{ Index } & \multicolumn{2}{|c|}{$\begin{array}{l}\text { Two products separated in } \\
\text { mine plants }\end{array}$} & \multirow{2}{*}{$\begin{array}{c}\text { Unseparated } \\
\text { product }\end{array}$} \\
\hline & & $\begin{array}{c}\text { Existing cost } \\
\text { distribution }\end{array}$ & $\begin{array}{c}\text { Objective cost } \\
\text { distribution }\end{array}$ & \\
\hline Cost of run-of-mine oil shale (ROM), €/t & $C_{\mathrm{ROM}}$ & 5 & 5 & 5 \\
\hline Yield from ROM, \% & $S$ & & & \\
\hline Fuel oil shale (FOS) & $s_{\mathrm{FOS}}$ & 40 & 40 & 63 \\
\hline Process oil shale (POS) & $s_{\mathrm{POS}}$ & 17 & 17 & 0 \\
\hline Total: Trade oil shale (TOS) & $s_{\mathrm{TOS}}$ & 57 & 57 & 63 \\
\hline \multicolumn{5}{|l|}{ Cost price, $€ / t$} \\
\hline Fuel oil shale & $C_{\mathrm{FOS}}$ & ND & 7.94 & 7.94 \\
\hline Process oil shale & $C_{\mathrm{POS}}$ & ND & 32.93 & - \\
\hline Trade oil shale & $C_{\mathrm{TOS}}$ & 8.77 & 8.77 & 7.94 \\
\hline \multicolumn{5}{|l|}{ Cost of energy, $€ / G J$} \\
\hline Fuel oil shale & $C E_{\mathrm{FOS}}$ & ND & 0.97 & 0.97 \\
\hline Process oil shale & $C E_{\mathrm{POS}}$ & ND & 3.19 & - \\
\hline & $C E_{\mathrm{TOS}}$ & 0.97 & 0.97 & 0.97 \\
\hline \multicolumn{2}{|c|}{ Index in formula } & & 2 & \\
\hline
\end{tabular}
process oil shale and separated waste.

Table 1. Oil shale separation indexes

Remarks:

- Cost of run-of-mine oil shale is illustrative

- $\quad \mathrm{ND}$ - no data

- The objective cost of processing oil shale for separating two products is calculated as follows:

$C_{\mathrm{POS} .2}=\left(C_{\mathrm{TOS} .1}-C_{\mathrm{TOS} .3} \times s_{\mathrm{FOS} .1} / 100\right) /\left(s_{\mathrm{POS} .1} / 100\right)=(8.77-7.94 \times 40 / 100) /$ $(17 / 100)=33.93 € / \mathrm{t}$ 
A corresponding calculation on the example of the underground oil shale mine Estonia is presented in Table 1. These calculations demonstrate that if the mines do not separate high calorific POS, the production capacity of the mine will be higher, the loss of organic matter lower, and cost price $\left(C_{\mathrm{TOS}}\right)$ of the product lower. In the case of continuing separation, the price of POS for old-type oil generators should be the objective. It should cover the expenses of separation and must be up to four times higher than the price of oil shale for electricity generation (FOS) [4-8]. In reality, the cost of POS as well as its cost of energy is today lower than objective costs $C_{\mathrm{POS} .2}$ and $C E_{\mathrm{POS} .2}$ demonstrated in Table 1.

A subvention for POS was established at the time of specifying cut-offgrades already. Old-type oil generator was not considered at calculations of oil shale reserve [2,9]. Since the LOS-process is uneconomic, it is still not considered today. Oil shale resource has to be calculated for the SHCprocess that is currently being developed and introduced in Estonia.

The basic calculation has been performed with the spatial modelling method. Oil shale undeground mine Estonia has been taken as marginally economic. In accordance with the main mining conditions (seam thickness, seam calorific value, calorific value of oil shale layer and indexes of thickness), potential oil yield distribution was modelled in the area of the deposit [10-12]

For calculating technical oil yield, real amount and cost price of oil production, the efficiency of generators and losses at processing have to be taken into account. The efficiency of energy yield at combustion and oil generation processes depend on the quality of fuel and raw material in the same way as the efficiency data in Fig. 1.

The dependence between calorific value of oil shale and the efficiency of units is described by the formula

$$
\eta=k-l / Q
$$

where: $Q$-calorific value, $\mathrm{MJ} / \mathrm{kg}$

$k$ - marginal efficiency in a given unit, achieved using raw material of the highest quality, \%

$l$ - equation parameter, $\mathrm{MJ} / \mathrm{kg}$, as related to the minimum quality of the raw material $l=k Q_{\text {min }}$.

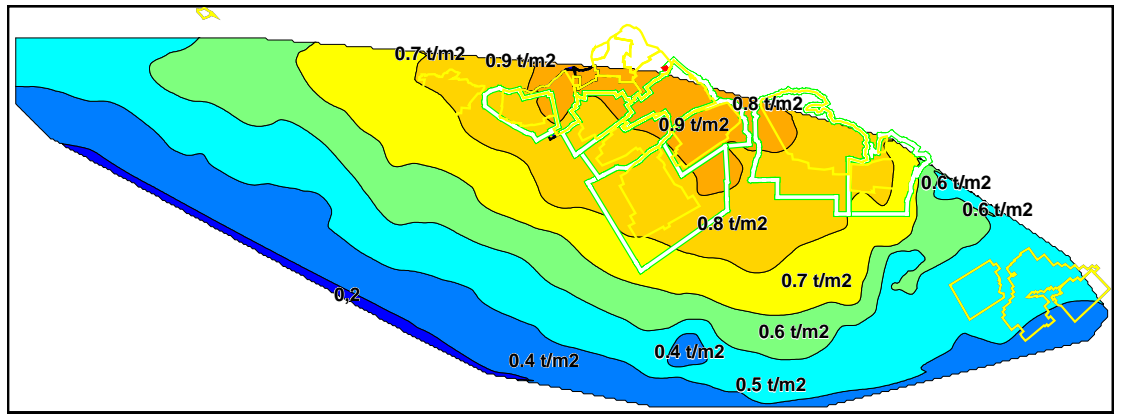

Fig. 1. Oil yield in the area of exploration fields, $\mathrm{t} / \mathrm{m}^{2}$ 
Table 2. The parameters in the formula of the efficiency of oil shale utilisation

\begin{tabular}{|l|c|c|c|c|}
\hline \multicolumn{1}{|c|}{ Unit utilising oil shale } & $k$ & $\begin{array}{c}l, \\
\% \mathrm{MJ} / \mathrm{kg}\end{array}$ & $\begin{array}{c}Q_{\min }, \\
\mathrm{MJ} / \mathrm{kg}\end{array}$ & Data from reference \\
\hline Circulating fluidized bed boiler & 98.3 & 34.5 & 0.35 & {$[13]$} \\
Boiler TP17 (pulverised oil shale) & 92.2 & 81.2 & 0.88 & {$[14]$} \\
SHC retort (not measured) & $85-90$ & $80-100$ & $0.5-1$ & Author's speculation \\
LOS retort & 85.3 & 118 & 1.38 & {$[15]$} \\
\hline
\end{tabular}

The LOS-process is characterized by low marginal efficiency and the highest losses of organics with wastes (Fig. 2).

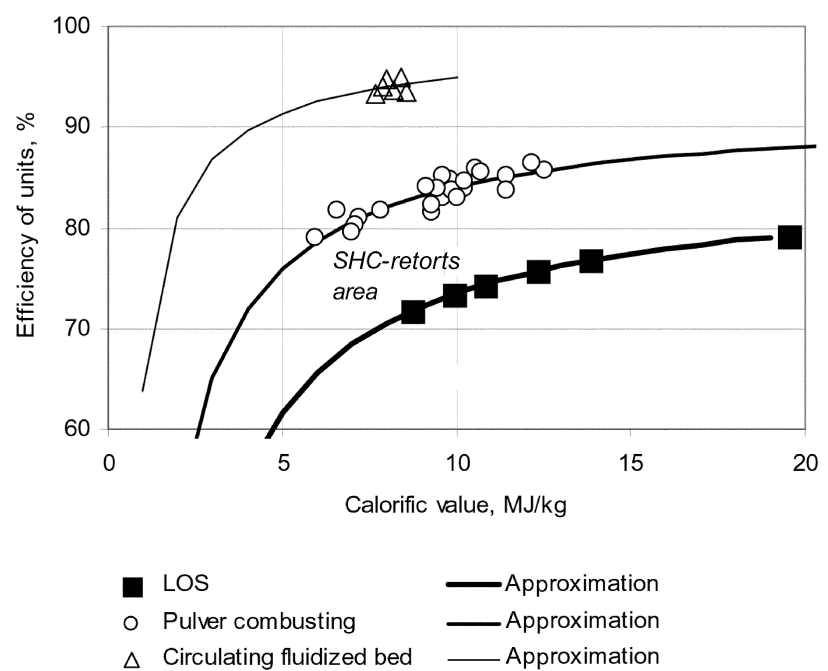

Fig. 2. Dependence between calorific value and efficiency of units

The consumer of oil shale is interested in product quality. On the one hand, better quality of the raw material or fuel allows reduction of costs for transportation, processing and burning, and, on the other hand, it ensures higher quality of processing and cleaner environment. Hence, with regard to the utilization (processing, burning), mineral raw material of higher quality is beneficial. The main instrument to regulate the quality of oil shale is the price. Oil shale price is strongly conservative today - in practice it does not depend on calorific value of oil shale and cannot control oil shale flow [16]. 


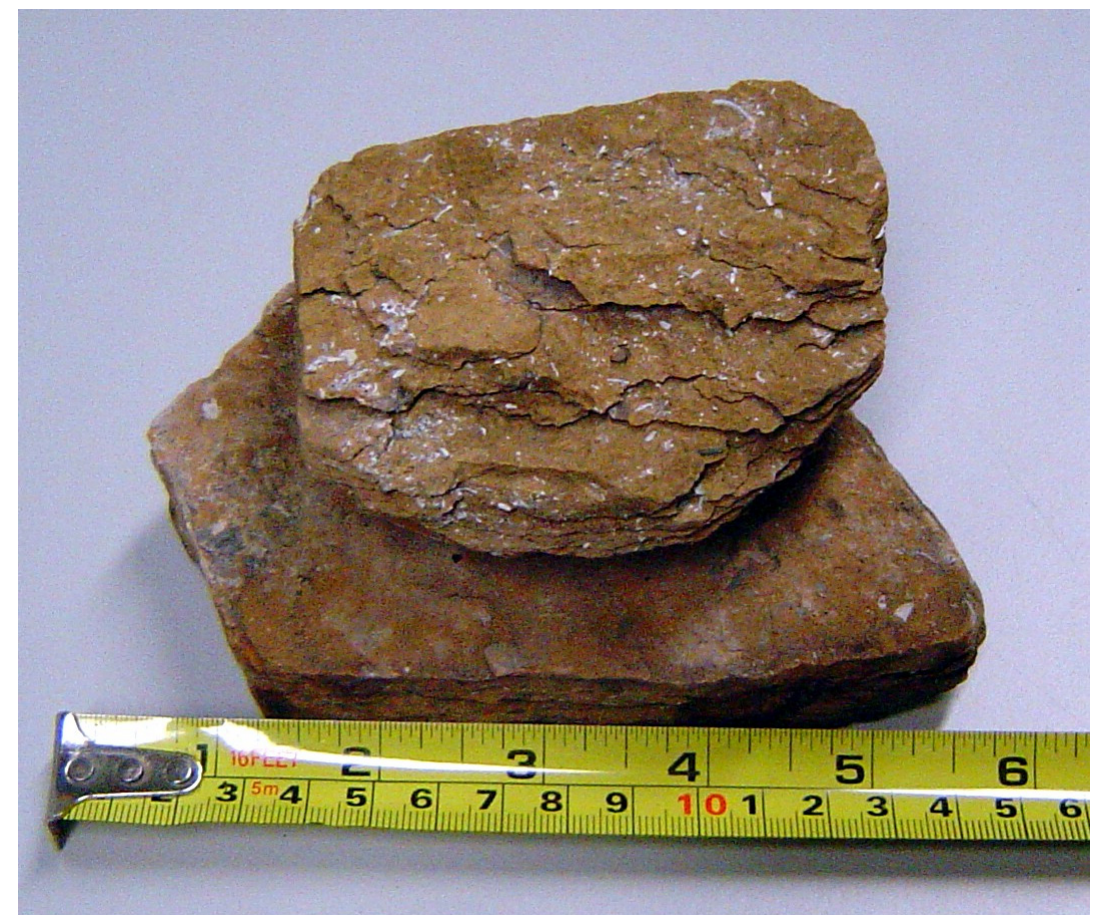

Fig. 3. Unprocessed oil shale pieces from the LOS-process waste dump

\section{Conclusions}

- This study offers a classical optimising equation resulting in determination of the optimal quality (calorific value and grain size) of fuel and raw material, optimal resource and tuneable prices for trade oil shale flow.

- According to the economy of new oil industry, the mineable resource of Estonian oil shale could increase.

\section{Acknowledgements}

Financial support by the Estonian Science Foundation, Grant No. 5913, is highly appreciated.

\section{REFERENCES}

1. Koitmets, K., Reinsalu, E., Valgma, I. Precision of oil shale energy rating and oil shale resources // Oil Shale. 2003. Vol. 20, No. 1. P. 15-24.

2. Reinsalu, E. Criteria and size of Estonian oil shale reserves // Oil Shale. 1998. Vol. 15, No. 2. P. 111-133. 
3. Valgma I. Oil shale mining in Estonia and Russia // Encyclopaedia of Life Support Systems. EOLSS Publishers Co. Ltd, Oxford UK, 2000.

4. Reinsalu, E. Economical aspects of oil shale mining and its use in power engineering // Estonian-Finnish Energy Seminar, Helsinki: 1994, P. 15-19.

5. Reinsalu, E. Is Estonian oil shale beneficial in the future? // Oil Shale. 1998. Vol. 15, No. 2 Special. P. 97-101.

6. Reinsalu, E. An acceptable scenario for oil shale industry // Oil Shale. 1999. Vol. 14, No. 4. P. 289-290.

7. Reinsalu, E. Oil shale mining // Estonian energy 2002, 2003. P. 24-30.

8. Reinsalu, E. Oil shale industry in Estonia at a crossroads // Oil Shale. 2005. Vol. 22, No. 3. P. 259-260.

9. Reinsalu, E. Stochastic modelling in Estonian oil shale mining economics // Oil Shale. 1999. Vol. 16, No. 4. P. 377-382.

10. Valgma, I. Estonian oil shale resources calculated by GIS method// Oil Shale. 2003. Vol. 20, No. 3. P. 404-411.

11. Valgma, I. Geographical Information System for Oil Shale Mining - MGIS. (Doctoral Thesis) Tallinn: Tallinn Technical University Press, 2002.

12. Valgma, I. Using MapInfo Vertical Mapper Interpolation Techniques for Estonian Oil Shale Reserve Calculations // Proceedings of the International Conference on Corporate Finance Management in Mining Industry, Bulgaria: 2002. CD-B Press

13. Arro, H., Pihu, T., Prikk, A. The need for process and transmission efficiencies of electric power and development scenarios for Estonian power system in 2005-2015. The report of the contract 478. Department of Thermal Engineering of TUT. Tallinn, 2004 [in Estonian].

14. Ots, $A$. Research on operation of boiler TP-17 combusting nonenriched oil shale from open casts. Department of Thermal Engineering of TUT. Tallinn, 1964 [in Russian].

15. Jefimov, $V$., Piik, E. Dependence of oil yield and chemical efficiency of gas producer on quality of feed oil shale // Bulletin Oil Shale. 1972, No. 4. P. 14-23 [in Russian].

16. Reinsalu, E. Relationship between crude mineral cost and quality // Mineral Resources Engineering. 2000. Vol. 9, No. 2. P. 205-213.

Received December 1, 2006 